\title{
Modelling asymmetric relationship between exports and growth in a developing economy: Evidence from Namibia
}

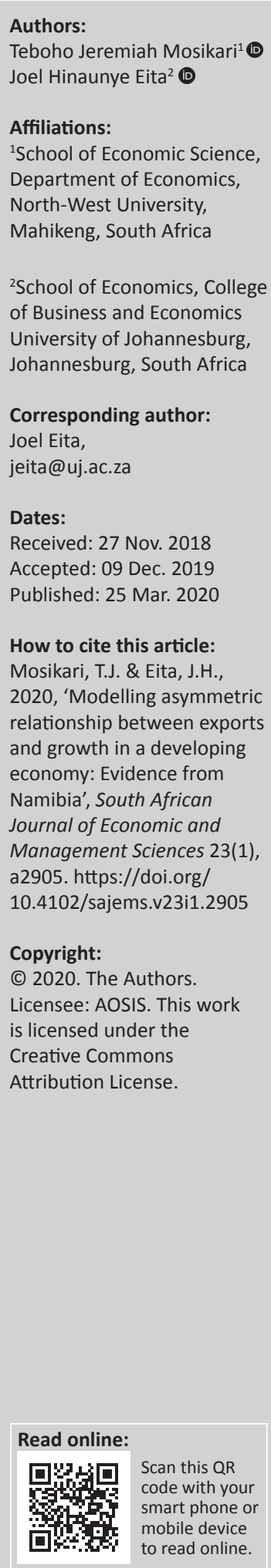

Background: Namibia is an open economy where international trade accounts for a greater proportion of gross domestic product (GDP). Openness of the Namibian economy for the period 2010 to 2018 has been on average 111\% of GDP. The high level of openness of the economy raised an important question on the relationship between export and economic growth in Namibia. Previous studies investigated the linear relationship between these two variables. The investigation was also done at an aggregate level. This raises important questions on whether the relationship between export and economic growth is asymmetric. It also raises an important question on whether this relationship is sector specific.

Aim: In order to fill the gap in previous research, this study investigates the asymmetric or non-linear relationship between the main export sectors and economic growth in Namibia. A non-linear relationship between the two variables will indicate that negative and positive values of the explanatory variables have different effects on the dependent variable. This analysis is done for the main export sectors of the Namibian economy in order to ensure the policy recommendations are sector specific.

Setting: Standard economic theoretical models on the relationship between export and economic growth are used to test the non-linear relationship between the two variables. The study covers the period 2010-2018 and focuses on the three main export sectors (diamonds, manufactured food and live animal products) and growth of the Namibian economy.

Methods: This study uses non-linear autoregressive distributive lag in order to estimate the asymmetric relationship between the main export sectors and economic growth of Namibia. The estimation is done for the three main exporters of the Namibian economy.

Results: The results indicate that there is a symmetric relationship between main export sectors and economic growth of the Namibian economy. The results show that an increase (positive values) in export of the three main export products will cause economic growth to improve. Negative values (decrease in export) will cause economic growth to deteriorate.

Conclusion: The results suggest that estimating the non-linear relationship for different sectors of the economy (instead of estimating the relationship at aggregate level for total exports) will ensure that economic policies are sector-specific. The results further suggest that when exports are declining, expansionary policies will be the appropriate responses.

Keywords: Economic growth; export; asymmetric modelling; non-linear autoregressive distributive lag; NARDL; Namibia; unit root; cointegration; Breitung; Kapetanios, Shin, Shell; KSS.

\section{Introduction}

The relationship between export and economic growth has received considerable attention in the literature. This relationship is important in the sense that it addresses central questions of how a country can accelerate economic growth through increase in exports (Rangasamy 2009). Studies such as Salvatore (2011) argued that most countries are subject to weakening strategy of industrialisation. The problem of weakening strategy of industrialisation can be overcome through import substitution. It is important to mention that most economies have been moving away from import substitution to industrialisation strategy that is export-oriented.

The Keynesian demand side theory postulates that export is very important for economic growth. This postulation has been supported by studies such as Helpman and Krugman (1985), and Aladejare and Saidi (2014). According to these studies, export is a key driver to economic growth. Countries can expand their domestic market by exporting more products. This will accelerate their 
economic growth. Rangasamy (2009) also supports the role of exports in accelerating economic growth, by stating that increase in export helps developing countries that have smaller and limited domestic markets to gain from economies of scale. This argument is relevant especially for countries that have smaller populations. It is also important to mention that if a country produces and exports products where it has comparative advantage, local industrialisation will be sped up. Dritsakis (2006) also argues that developing countries that have more open economies and export more to the rest of the world will have opportunities to absorb the necessary technologies and innovations. These are technologies and innovations that come from advanced economies and can help developing economies to prosper through increase in exports.

There are many studies that support an export-led strategy. These studies argue that an outward-oriented export strategy is very important for economic growth and industrialisation (Dollar \& Kraav 2005; World Bank 1993). According to these studies, countries that are open to international trade tend to achieve higher economic growth. Economies that are less open to international trade experience low economic growth. The views in favour of export-led growth is reinforced by the experience of countries in East Asia. These countries adopted an export-led industrialisation strategy and experienced high economic growth. The experience of East Asian countries led to many developing countries to adopt export-led growth strategies. Namibia is among the developing countries that adopted an export-led growth strategy after attaining its independence in 1990 from South Africa's colonial occupation. Namibia has a limited domestic market because of its smaller population which is currently 2.4 million. Hence, it adopted an export-led growth strategy in order to expand its limited domestic market and accelerate its economic growth.

Namibia is richly endowed with natural resources such as gold, diamond, copper, coal, uranium and other rare earth minerals. Despite the fact that Namibia is endowed with natural resources and world-class infrastructure, its economy is not properly diversified. The country relies on the export of a few products (such as diamonds, manufactured products processed fish, beverages, meat - food and live animals). Namibia is an open economy where trade accounts for a significant proportion of its gross domestic product (GDP). Phiri and Bhatia (2017) state that the country's openness (sum of import and export to GDP) increased from 104.6\% in 2014 to $111.5 \%$ in 2015. Data from Namibia Statistics Agency (NSA) show that the main destination of Namibia's exports is South Africa. South Africa accounted for 24\% of Namibia's exports in 2017. Other main trading partners are Botswana (13\% of Namibia's exports) and Switzerland $(10 \%$ of Namibia's exports). Countries such as Belgium, China and Spain accounted for $5 \%$ of Namibian export.

Empirical studies on the relationship between exports and economic growth in Namibia are limited. However, there are some notable studies such as Amavilah (2003), Jordaan and
Eita (2007), and Ogbokor and Meyer (2016). These studies estimated a linear or symmetric relationship between exports and economic growth. These studies estimated the relationship between economic growth and export and at an aggregate level (total exports). With the exception of Amavilah (2003), these studies concluded that there is a positive relationship between export and economic growth in Namibia. These studies did not test the non-linear relationship between export and economic growth in Namibia. They also did not test the relationship between export and economic growth at sectoral level. That is because estimating the relationship between these variables at an aggregate level may not be appropriate as it may lead to blanket policies for all sectors even though sectors are different. For example, the mineral or diamond sectors may require policies that are different from that of food and live animals.

This study will differ from previous studies and contribute in the following ways. It will investigate the asymmetric (nonlinear) relationship between export and economic growth using the non-linear autoregressive distributive lag (NARDL) estimation technique. It will estimate the relationship between export and economic growth at sectoral level. Estimating the relationship between export and economic growth for different sectors ensures that there will be no blanket economic policies; it will ensure that the policies are sector-specific.

To the best of our knowledge, this is the first study to test the asymmetric relationship between export and economic growth in Namibia. It is also the first study to test the relationship between the two variables for different export sectors. The advantage of an asymmetric relationship between these variables is that it allows for an investigation of the impact of negative and positive effects of exports on economic growth in the long run. That means negative and positive values of exports will have different effects on economic growth. Therefore, the following research questions are to be investigated in this study. The first is whether there is an asymmetric relationship between exports and growth in Namibia. This will be tested for the main export sectors of the Namibian economy. The second question is on the magnitude and size of economic growth due to changes in exports in the long run. This will also be investigated for the main export sectors of the Namibian economy. The rest of this article is structured as follows. The following section discusses briefly Namibia's export-led growth policy. This is followed by a presentation of the empirical literature, then a section providing the methodology, empirical model, and estimation technique and data description. Next is a section presenting the empirical results and the final section concludes the study.

\section{Brief review of Namibia's export-led growth policy}

Namibia adopted an outward looking or export-led growth strategy since its independence in 1990. Namibia is an open economy and has been historically integrated with South Africa through its membership of the Southern African Customs Union (SACU). Namibia formally became a member 
of SACU immediately after its independence from South Africa. It also joined the World Trade Organisation (WTO) in 1995. According to the United Nations Conference on Trade and Development (UNCTAD 2016), Namibia joined the European Economic Community - Cotonou agreement as a matter of priority. This agreement granted Namibia access to the European market. This enabled Namibia to have access to the export quota of 13000 tonnes of beef duty free into the European market. A little duty free beef export quota to Norway was also granted to Namibia. Namibia has a limited market size and the government acknowledged that export is important for accelerating economic growth.

Due to the small market, it was therefore decided that it is important to shift the development strategies of Namibia from inward to outward looking. Among the outward strategies are the Export Processing Zones (EPZ) established in 1995, Export Development Strategy of 1998, Vision 2030 and National Development Plans, industrial and competition policies, and Trade Management Act. The EPZ was established in 1995 and its aim is to attract investment in production for export. Transfer of skills to Namibians was also another aim of the EPZ. The EPZ offers incentives tax exemption, protection from pressures of trade unions and incentives related to training. According to Jordaan and Eita (2007), firms in EPZ that manufacture and export products are exempted from paying import duties on intermediate inputs. The EPZ is still in existence and has assisted Namibia in expanding its exports. However, there have been concerns that its contribution to the Namibian economy was minimal. It generated less jobs than anticipated. Exports from the EPZ were lower than anticipated. This led to the Offshore Development Company (ODC) under the Ministry of Industrialisation, Trade and Small and medium-sized enterprises (SME) Development to commission a study in 2012 on the performance, cost and benefit of the EPZ. Among others, the commissioned study was expected to cover the EPZ programme, institutional review and realignment, cost and benefit (of the EPZ). The study has not yet been made public, but it is expected to be released in 2020 .

The Export Development Strategy of 1998 prioritised the processing of minerals, mariculture and agriculture. The emphasis of this strategy is to ensure that Namibia moves away from exports of primary to processed or secondary products. Other sectors such as tourism, which have the potential to generate high income, are also considered as priorities.

Vision 2030 was adopted in 2004. Vision 2030 is an aspirational policy document, which set out Namibia's industrialisation tone and on which the country's trade policy is hinged. The objective of this document is to attain stability, regional integration and international relations that are democratised. According to Vision 2030, manufacturing and the service sectors are expected to account for $80 \%$ of Namibia's GDP, and processed products should dominate export. Agriculture, tourism, mining, and logistics are identified by Vision 2030 as priority sectors. These priority sectors will be strengthened by improved infrastructure such as road, rail, port and telecommunications. These will transform Namibia into an industrialised economy that will have GDP per capita equivalent to that of advanced economies. Namibia also has medium-term plans called National Development Plans. The Fourth and Fifth National Development Plans consider logistics, agriculture, tourism and manufacturing as keys to industrialising Namibia. These priority sectors are complemented by improved education that will enhance the country's capacity to trade and improve economic development. Concerted investment is aimed at creating the pool of expertise to complement Namibia's export and economic development. Vision 2030 is an ambitious policy document, but Namibia's exports are still dominated by commodities with limited or basic processed products. However, UNCTAD (2016) statistics from the Bank of Namibia (BON) indicated that the services sector accounts for a substantial of component of Namibia's GDP.

The country has launched Namibia's Industrial Policy in recent years (UNCTAD 2016). According to Namibia's Industrial Policy document, industrialisation is important for accelerating inclusive economic growth and development, job creation, wealth and poverty alleviation. This will take place in the context of an open economy that is integrated within its region, compliance with WTO and protection of infant industries. Market integration, development of infrastructure, fair competition, incentives to manufacturers for export and skills development are considered as key instruments of Namibia's Industrial Policy document. The Namibian government also launched the Growth at Home Strategy in 2015, which is the execution strategy for achieving Namibia's industrialisation as outlined in its Industrial Policy of 2012. It connects the country's industrial policy to its socio-economic development. It emphasises an increase in diversified production as very important for regional integration. It focuses on supporting value addition and diversification for growth that is sustainable. It is expected that these will improve the local investment climate and secure market at home and abroad. The expectation is that if this policy is successfully implemented, there will be an increase in value-added export. According to the Growth at Home Strategy, this can only be achieved if the government enhances capacity in priority sectors such as agro-processing, fish processing, manufacturing of steel, fabrication of metals, chemicals and beneficiation of minerals. The plan is to have value-added export growing by $10 \%$ per year. It is also expected that valued or processed exports will account for at least $10 \%$ of exports. Despite that, it is important to mention that it will not be easy for Namibia to have its exports dominated by valueadded or processed products. That is because Namibian export is still dominated by primary products (although there has been an increase in some value-added products).

\section{Empirical literature}

The relationship between exports and growth in developing countries has attracted considerable attention in the literature (such as Aladejare \& Saidi 2014; Busse \& Königer 2012). Internationally, a cross section study by Din (2004) examines the export-led growth hypothesis for the five largest economies 
of the South Asia region. The study used a multivariate timeseries framework for the study period 1960-2002. The results show that there is a long-run relationship between exports, imports, and output for Bangladesh and Pakistan. However, for India, Nepal, and Sri Lanka, no evidence of a long-run relationship was established. Furthermore, Busse and Königer (2012) examine the causal linkage between trade and growth in a group of 108 countries. The study uses the generalised method of moments estimation technique for a sample covering the period 1971-2005. The results provided evidence that the growth of trade through its associated access to additional technologies has a significant impact on income growth.

There are also empirical studies in the literature that are country specific. Mishra (2011) attempted to investigate the dynamics of the relationship between exports and economic growth for India over the period 1970-2009. The study applied the popular econometric techniques of cointegration and vector error correction estimation techniques. The findings indicate the existence of the cointegration between exports and real GDP in India. Shihab and Abdul-Khaliq (2014) examined the causal relationship between economic growth and exports in Jordan. The study used the Johansen cointegration test for period covering 2000-2012. The results show that there is evidence of causality between export and economic growth in Jordan and the direction of causality runs from economic growth to exports. Gurgul and Lach (2010) studied the linear and non-linear causalities between international trade and economic growth in the Polish economy. The study examined two samples for the period (Q1 1996-Q3 2009) and the pre-crisis sample (Q1 1996Q3 2008). The results of the study indicate that feedback exists between the real growth rate of GDP and the real growth rate of exports. In addition, Mtaturu (2016) analysed the relationship between export and economic growth in Tanzania using the Engle-Granger cointegration technique. The study found that there is no indication of cointegration between exports and economic growth in Tanzania. Aladejare and Saidi (2014) examined the impact of the aggregate non-oil sector and its determinant on economic growth of Nigeria. The bound test approach was employed to examine the phenomena for the sample period of 1970-2012. The results show a strong support for a long-run relationship between non-oil export and economic growth in Nigeria. Molapo and Damane (2016) empirically examined the relationship between mining exports and economic growth in Lesotho. The study tested the export-led growth hypothesis using annual time series data covering the period 1970-2013. It applied the autoregressive distributed lag (ARDL) technique and revealed that there is a long-run relationship between mining exports and economic growth.

There are few empirical studies on the relationship between export and economic growth in Namibia. Amavilah (2003) maintained that for Namibia, domestic export supply factors are more important to growth than external demand factors. This was followed by Jordaan and Eita (2007) who studied the relationship between exports and economic growth in Namibia for the period 1970-2005. This study used the Johansen cointegration technique to investigate the relationship between export and economic growth. The study found that there exists a long-run relationship between exports and economic growth. This was supported by Niishinda and Ogbokor (2013), who investigated the export and economic growth relationship for Namibia. The study applied the Johansen cointegration test for the period 1972-2010 to examine the nature of the relationship. The findings show that various measures to increase export can enhance economic growth in Namibia. Promotion of export has been the catalyst in modern economies to sustain economic growth in most developing nations. Simasiku and Sheefeni (2014) engaged in a study to determine how changes in terms of trade have an effect on growth in Namibia. The results show an indirect relationship between terms of trade and economic growth in Namibia. Ogbokor (2015) studied the impact of foreign trade on growth in the Namibian economy. The study applied two modern econometric time series methods: vector autoregressive (VAR) and ARDL models. The study revealed that the economy of Namibia can be expanded potentially by means of foreign trade. Simasiku and Sheefeni (2017) investigated the nexus between agricultural export and economic growth in Namibia for the period 1990-2014. The study confirmed that the cointegration test indicated that there is a long-run relationship between agricultural export and economic growth in Namibia.

Many previous studies on Namibia (such as Amavilah 2003; Jordaan \& Eita 2007; Niishinda \& Ogbokor 2013; Ogbokor \& Meyer 2016; Simasiku \& Sheefeni 2017) have modelled the relationship between export and economic growth using a linear approach. However, this approach may seem inappropriate especially when the economic variables integrate non-linear characteristics of the business cycle in exports over time. According to Hatem and Uddin (2012), it is important to allow for an asymmetric or non-linear relationship between the variables of interest in the study. This study further indicated that allowing for an asymmetric relationship is crucial in the sense that the effect of negative shock of exports can be different from the positive shocks of exports on growth. Therefore, the main contribution of this study is to explore the asymmetric effect of exports on growth in Namibia. The analysis of this study will not be for aggregate export, but will be done for the main export sectors of the Namibian economy. To the best of our knowledge, this might be the first study to apply NARDL to examine export and growth in Namibia. It will also be the first study to investigate the non-linear relationship for the main export sectors of the Namibian economy. An investigation of the non-linear relationship between export and growth at sectoral level will ensure that there will be no blanket economic policies for all sectors; the economic policies will be sector-specific.

\section{Methodology: empirical model, estimation technique and data description Empirical model}

Following an extensive review of the empirical literature on exports and economic growth, the long-run relationship between the two variables is specified as follows: $G D P_{t}=\beta_{0}+\beta_{1} X P O T_{t}+\mu_{t}$

[Eqn 1] 
$G D P_{t}$ is the GDP (representing economic growth), XPOT represents disaggregate exports (of manufactured products, diamonds and food and live animals), $\beta_{1}$ is the long-run coefficient for disaggregated exports and $\beta_{0}$ is the intercept. The variable $\mu_{t}$ represents the error term. Equation 1 will be estimated at disaggregated level. That means that the equation will be estimated for manufactured products, diamonds, and food and live animals. This is contrary to previous studies which estimated the relationship between export and economic growth at aggregate level.

\section{Estimation technique}

To capture for asymmetries Shin, Yu and Greenwood-Nimmo (2014) developed the NARDL model where exports can be decomposed into negative and positive partial sums. Then, Equation 1 is re-specified in non-linear form as follows:

$$
G D P_{t}=\beta_{0}+\beta_{1} G D P_{t-1}+\beta_{2}^{-} X P O T_{t-1}^{-}+\beta_{3}^{+} X P O T_{t-1}^{+}+\mu_{t} \quad \text { [Eqn 2] }
$$

According to Equation 2 the long-run relationship between economic growth and disaggregated decrease in exports is measured by $\beta_{2}^{-}$. The relationship between economic growth and disaggregated increase in exports is captured by $\beta_{3}^{-}$. In the long run both disaggregated increase and decrease in exports are expected to have a positive effect on economic growth. Therefore, the long-run relationship between disaggregated exports and economic growth presented in Equation 2 reflects asymmetric characteristics. Following the presentation of Equation 2 in non-linear form, there are some properties which are determined in Equation 3 and Equation 4 to give the partial sums of positive and negative changes in $\mathrm{XPOT}_{t}$ :

$$
\begin{aligned}
& X P O T_{t}^{+}=\sum_{i=1}^{t} \Delta X P O T_{t}^{+}=\sum_{i=1}^{t} \max \left(\triangle X P O T_{J}, 0\right) \\
& X P O T_{t}^{-}=\sum_{i=1}^{t} \Delta X P O T_{t}^{-}=\sum_{i=1}^{t} \min \left(\Delta X P O T_{J}, 0\right)
\end{aligned}
$$

Equation 2 is augmented with control variables and respecified (in the NARDL form) in Equation 5. The variables $I M P_{t}$ and $I N F_{t}$ are imports and inflation. Other variables are as previously defined:

$$
\begin{aligned}
& \Delta G D P_{t}=\beta_{0}+\beta_{1} G D P_{t-1}+\gamma_{1}^{-} X P O T_{t-1}^{-}+ \\
& \gamma_{2}^{+} X P O T_{t-1}^{+}+\gamma_{3}^{-} I M P_{t-1}^{-}+\gamma_{4}^{+} I M P_{t-1}^{+}+ \\
& \gamma_{5}^{-} I N F_{t-1}^{-}+\gamma_{6}^{+} I N F_{t-1}^{+}+ \\
& \sum_{i=1}^{p-1} \theta_{i} \Delta G D P_{t-1}+\sum_{i=0}^{q} \pi_{1}^{+} \Delta X P O T_{t-1}^{+}+ \\
& \sum_{i=0}^{q} \pi_{2}^{-} \Delta X P O T_{t-1}^{-}+\sum_{i=0}^{q} \pi_{3}^{+} \Delta I M P_{t-1}^{+}+ \\
& \sum_{i=0}^{q} \pi_{4}^{-} \Delta I M P_{t-1}^{-}+\sum_{i=0}^{q} \pi_{5}^{+} \Delta I N F_{t-1}^{+}+ \\
& \sum_{i=0}^{q} \pi_{6}^{-} \Delta I N F_{t-1}^{-}+\mu_{t}
\end{aligned}
$$

$q$ and $p$ are lag orders, and long-run coefficients are computed as $\beta_{2}=\gamma^{-} / \beta_{1}$ and $\beta_{3}=\gamma^{+} / \beta_{1}$. In addition, $\sum_{i=0}^{q} \pi_{i}^{+}$captures the short-run impact of disaggregated increase in exports on economic growth, while $\sum_{i=0}^{q} \pi_{i}^{-}$captures the short-run impact of disaggregated decrease in exports on economic growth in
Namibia. To examine the long-run cointegration between disaggregated exports and GDP growth, the article applies the stepwise ordinary least squares model to estimate Equation 5 which uses a general-to-specific procedure. After estimating NARDL, the study performs a test for long-run cointegration using the bounds testing approach (Pesaran, Shin \& Smith 2001). This approach uses the Wald $F$-testing with the null hypothesis, $\gamma_{1}=\cdots_{. .}=\gamma_{6}=0$ which implies 'no cointegration'. Finally, the article also uses Wald F-test to determine the asymmetric cointegration between disaggregated exports and economic growth in Namibia. However, before determining whether there exists a long-run relationship among the variables, the study needs to investigate the non-linearity for each variable. It uses the Brock, Dechert, Scheinkman (BDS) test to determine non-linearity. The test was developed by Brock et al. (1996). It can be used for testing against a variety of possible deviations from linear and non-linear dependence. Following, the study adopts the unconventional non-linear unit root test of Kapetanios, Shin, Shell (KSS) by Kapetanios, Shin and Snell (2003) and Breitung nonparametric unit root by Breitung (2002).

\section{Data description}

The article uses quarterly data from the period 2009-2018. Data were obtained from the BON and NSA. This period was chosen because of data availability. The main export sectors of the Namibian economy were chosen due to consistent data availability. Table 1 provides data description for variables that are used in the study.

\section{Empirical results}

The descriptive statistics are presented in Table 2 . The variable that has lowest mean value is INF at $5.72 \%$. The variable that has the highest mean is GDP with a value N\$24 298.68 million. In addition to preliminary analysis the study examined each variable at levels and first difference. The study explored the time series plots of variables in levels and first difference

\begin{tabular}{|c|c|}
\hline Abbreviation & Measure of variable description \\
\hline GDP & $\begin{array}{l}\text { Gross domestic product at constant } 2010 \text { in million Namibia dollars } \\
\text { (N\$'000 000). This variable represents economic growth. This value } \\
\text { excludes exports. }\end{array}$ \\
\hline XРОТ & $\begin{array}{l}\text { Disaggregated exports: } \\
\text { - MNEXT: manufactured exports in } \mathrm{N} \$^{\prime} 000000 \\
\text { - DEXT: diamond exports in } \mathrm{N} \$^{\prime} 000000 \\
\text { - FHEXT: food and live animals exports in N\$'000 } 000\end{array}$ \\
\hline IMP & Imports of machinery, mechanical, electrical appliances in $\mathrm{N \$}(000000$ \\
\hline INF & Inflation rate \\
\hline
\end{tabular}
(the letter ' $\mathrm{L}$ ' at the beginning of each variable such LGDP shows that the variable is in logarithm). Figure 1 and Figure 2, therefore, present all the variables in the analysis in levels and first difference. Figure 1 shows that exports and economic growth seem to be moving in the same direction, but the movement seems not to be more linear. The same applies to Figure 2 where the variables are in difference form.

To test for the presence of non-linearity in the variables, this article employs the BDS test developed by Brock et al. (1996). 
It is conventional for any non-linear analysis to investigate the non-linearity in the variables used in the study. Table 3 presents the results of BDS test. The results show that the null hypothesis of independently and identically distributed has been rejected. This can be observed by all the $t$-statistics that are significant for each variable. This confirmed that the null hypothesis on

TABLE 2: Descriptive statistics.

\begin{tabular}{lrrr}
\hline Variable & \multicolumn{1}{c}{ Mean } & Maximum & Skewness \\
\hline FHEXT & 1807.975 & 2787.000 & 0.395520 \\
GDP & 24298.630 & 28302.000 & -0.367368 \\
IMP & 2638.187 & 4782.794 & 0.350690 \\
INF & 5.725 & 11.000 & 0.783023 \\
DEXT & 2053.100 & 3918.000 & -0.014899 \\
MNEXT & 3938.350 & 5967.000 & 0.429103 \\
\hline
\end{tabular}

FHEXT, food and live animals exports; GDP, Gross domestic product; IMP, imports of machinery, mechanical, electrical appliances; INF, inflation; DEXT, diamond exports; MNEXT, manufactured exports. non-linearity cannot be rejected since all the associated probability values are not greater than $1 \%, 5 \%$ and $10 \%$ significance levels. These test results imply the non-normal distribution of data which shows the behaviour of nonlinearity. The next step is to test the univariate characteristics (unit root) in the variables. The study uses the unconventional test of unit root. These are tests that are suitable for data that depict the non-normality over time. The study used KSS and Breitung non-linear unit root tests. To apply the KSS test, it is important to determine the lag length using Akaike information criterion (AIC), Shwartz information criterion (SIC) and Hannan quinine (HQ). The three criteria selected the optimum lag of 1 . Therefore, this lag of 1 was used to estimate the $t$-statistics for KSS procedure. The results are presented in Table 4 . The results in Table 4 show that the variables are nonstationary at levels. This is confirmed by comparing the
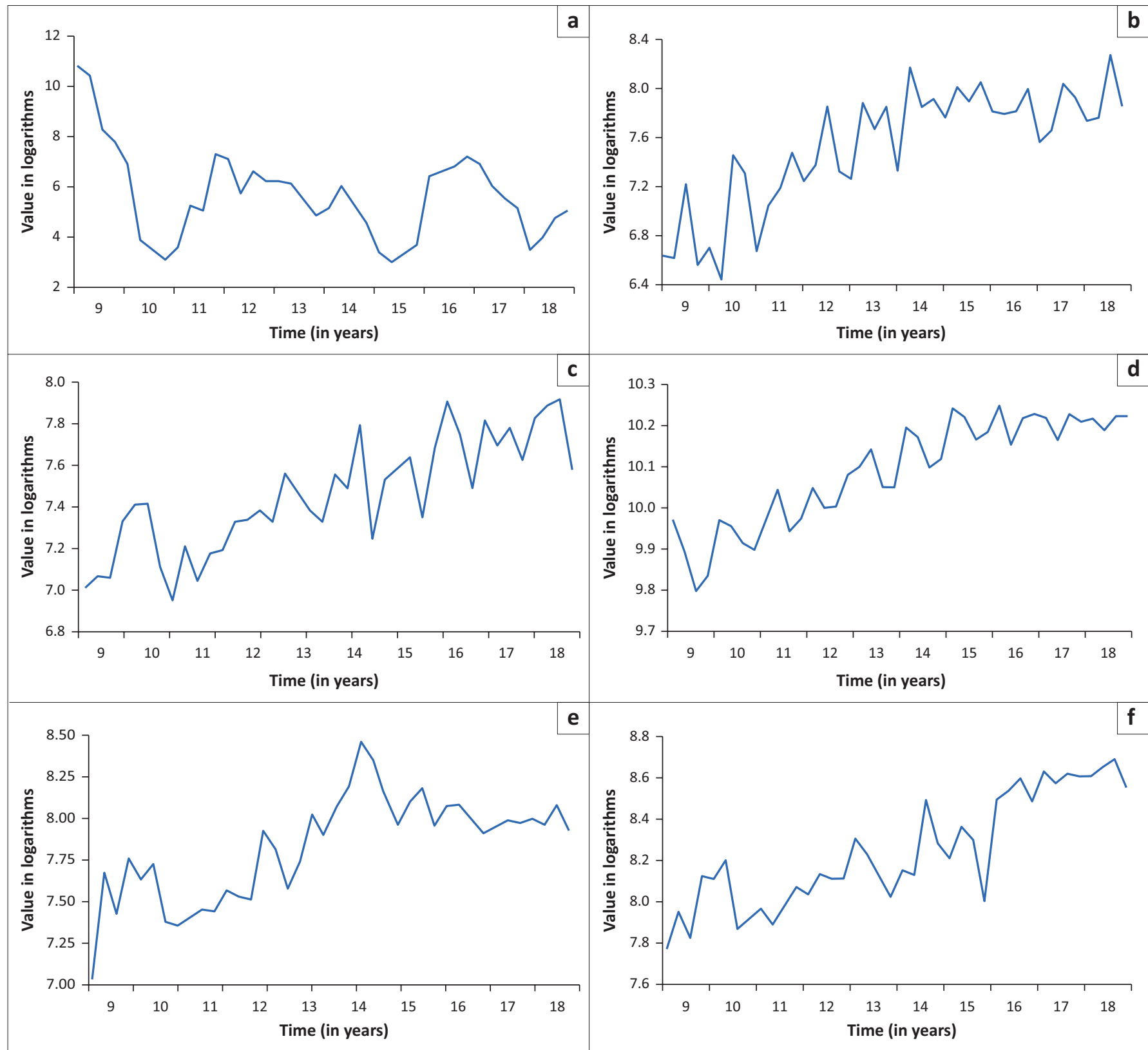

INF, inflation; LDEXT, diamond exports; LFHEXT, food and live animals exports; LGDP, Gross domestic product; LIMP, imports of machinery, mechanical, electrical appliances; LMNEXT, manufactured exports. FIGURE 1: Variables in levels: (a) INF; (b) LDEXT; (c) LFHEXT; (d) LGDP; (e) LIMP; (f) LMNEXT. 

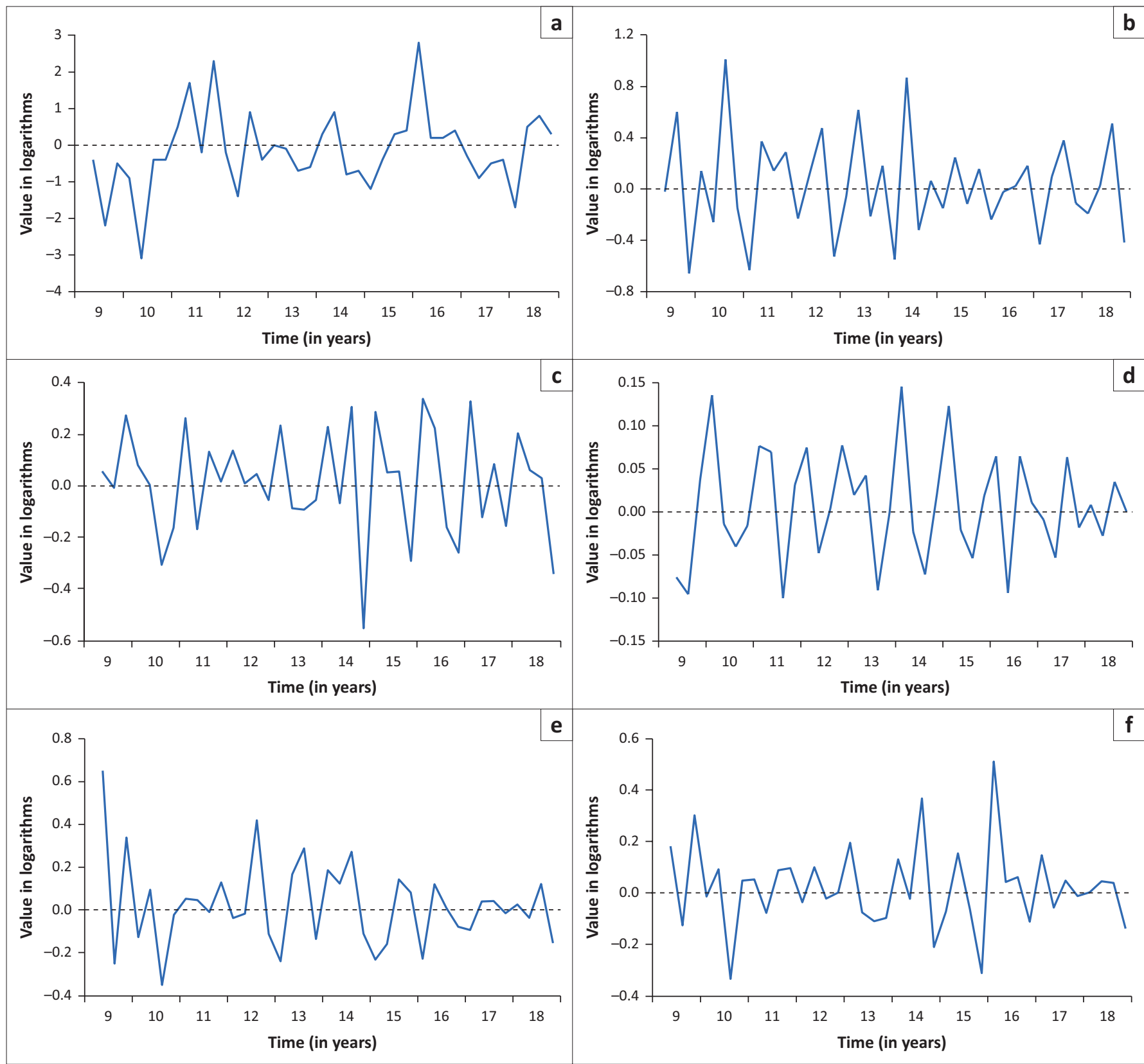

INF, inflation; LDEXT, diamond exports in logarithms; LFHEXT, food and live animals exports in logarithms; LGDP, gross domestic product in logarithms; LIMP, imports of machinery, mechanical electrical appliances in logarithms; LMNEXT, manufactured exports in logarithms.

FIGURE 2: Variables in first difference: (a) differenced INF; (b) differenced LDEXT; (c) differenced LFHEXT; (d) differenced LGDP; (e) differenced LIMP; (f) differenced LMNEXT.

$t$-statistics in the KSS table with KSS critical values. This further demonstrates that the null hypothesis of non-stationarity in the presence on non-linearity is present for all the variables.

This article also employs the Breitung non-linear unit root test. The tests only examine the intercept and the results are presented in Table 5. The results confirm that all variables are non-stationary at levels in the presence on non-linearity. It is now appropriate to estimate the NARDL cointegration between the main exports sectors and economic growth in Namibia. The results are presented in Table 6.

Table 6 presents the results for the NARDL cointegration test. As explained earlier, the relationship between export and economic growth (in Equation 5) is estimated at disaggregated level. The article has estimated Equation 5 in three different variations for the bound test procedure. Model I estimates the relationship between manufactured exports and economic growth. Model II estimates the relationship between diamond exports and economic growth. Model III estimates the relationship between food and live animals exports, and economic growth. The critical values in Table 7 are extracted from Narayan (2005). The results indicate that the computed $F$-statistics for all the models are greater than the upper bound critical value of 5.544 at $1 \%$ significance level. This implies that there is a long-run non-linear relationship between exports (disaggregated products) and economic growth in Namibia.

Table 7 presents long-run NARDL between export and economic growth. The results in Model I indicate that a 
TABLE 3: BDS test for non-linearity.

\begin{tabular}{|c|c|c|c|}
\hline Variable & Dimension & BDS statistics & Probability \\
\hline \multirow[t]{5}{*}{ LMNEXT } & 2 & 0.112 & 0.000 \\
\hline & 3 & 0.173 & 0.000 \\
\hline & 4 & 0.212 & 0.000 \\
\hline & 5 & 0.224 & 0.000 \\
\hline & 6 & 0.215 & 0.000 \\
\hline \multirow[t]{5}{*}{ LDEXT } & 2 & 0.085 & 0.000 \\
\hline & 3 & 0.140 & 0.000 \\
\hline & 4 & 0.204 & 0.000 \\
\hline & 5 & 0.253 & 0.000 \\
\hline & 6 & 0.276 & 0.000 \\
\hline \multirow[t]{5}{*}{ LFHEXT } & 2 & 0.078 & 0.000 \\
\hline & 3 & 0.116 & 0.000 \\
\hline & 4 & 0.132 & 0.000 \\
\hline & 5 & 0.147 & 0.000 \\
\hline & 6 & 0.166 & 0.000 \\
\hline \multirow[t]{5}{*}{ INF } & 2 & 0.134 & 0.000 \\
\hline & 3 & 0.211 & 0.000 \\
\hline & 4 & 0.242 & 0.000 \\
\hline & 5 & 0.255 & 0.000 \\
\hline & 6 & 0.268 & 0.000 \\
\hline \multirow[t]{5}{*}{ LGDP } & 2 & 0.117 & 0.000 \\
\hline & 3 & 0.210 & 0.000 \\
\hline & 4 & 0.292 & 0.000 \\
\hline & 5 & 0.351 & 0.000 \\
\hline & 6 & 0.392 & 0.000 \\
\hline \multirow[t]{5}{*}{ LIMP } & 2 & 0.102 & 0.000 \\
\hline & 3 & 0.181 & 0.000 \\
\hline & 4 & 0.227 & 0.000 \\
\hline & 5 & 0.264 & 0.000 \\
\hline & 6 & 0.275 & 0.000 \\
\hline
\end{tabular}

LMNEXT, manufactured exports in logarithms; LDEXT, diamond exports in logarithms; LFHEXT, Food and live animals exports in logarithms; INF, inflation rate; LGDP, Gross domestic product in logarithms; LIMP, imports of machinery, mechanical, electrical appliances in logarithms.

TABLE 4: Kapetanios, Shin, Shell test non-linear unit root results.

\begin{tabular}{lcccc}
\hline Variable & Estimate & $\boldsymbol{t}$-statistics & $\boldsymbol{p}$ & KSS critical value \\
\hline INF & 0.0021 & 2.091 & 0.043 & - \\
LMNEXT & 0.0020 & 3.521 & 0.001 & - \\
LGDP & 0.0010 & 3.201 & 0.002 & - \\
LFHEXT & 0.0036 & 4.768 & 0.000 & - \\
LDEXT & 0.0041 & 5.363 & 0.000 & - \\
LIMP & 0.0024 & 3.323 & 0.002 & - \\
$1 \%$ & - & - & - & -3.55 \\
$5 \%$ & - & - & - & -2.95 \\
$10 \%$ & - & - & - & -2.66 \\
\hline
\end{tabular}

KSS, Kapetanios, Shin, Shell test; INF, inflation rate; LMNEXT, manufactured exports in logarithms; LGDP, Gross domestic product in logarithms; LFHEXT, food and live animals exports in logarithms; LDEXT, diamond exports in logarithms; LIMP, imports of machinery, mechanical, electrical appliances in logarithms.

TABLE 5: Breitung non-linear unit root.

\begin{tabular}{lcc}
\hline Variable & Test statistics & $\boldsymbol{p}$-value \\
\hline INF & 0.0146 & 0.2000 \\
LMNEXT & 0.0804 & 0.8000 \\
LGDP & 0.0868 & 0.8667 \\
LFHEXT & 0.0708 & 0.7000 \\
LDEXT & 0.0367 & 0.9000 \\
LIMP & 0.0535 & 0.3000 \\
\hline
\end{tabular}

INF, inflation rate; LMNEXT, manufactured exports in logarithms; LGDP, Gross domestic product in logarithms: LFHEXT, food and live animals exports in logarithms; LDEXT, diamond exports in logarithms; LIMP, imports of machinery, mechanical, electrical appliances in logarithms.

decrease in exports of manufactured products has a coefficient of -0.164 , and it is not statistically significant. In addition, an increase in manufactured products has a coefficient of -0.703 and is statistically significant. Therefore, in the long run, a 1\% increase in exports of manufactured products will lead to a $0.344 \%$ increase in economic growth. However, a $1 \%$ decrease in exports of manufactured products will lead to a $0.080 \%$ decrease in economic growth of Namibia. In the long run, a $1 \%$ decrease in imports of machinery and other appliances will lead to a $0.227 \%$ decrease in economic growth. However, in the long run a $1 \%$ increase in imports of machinery will lead to a $0.104 \%$ increase in economic growth. In both cases the parameters for imports of machinery are statistically significant. The last, control variable which is inflation rate has the following impact: a $1 \%$ decrease in inflation rate will lead to $0.0003 \%$ decrease in economic growth. However, in the long run a $1 \%$ increase in inflation will lead to a $0.022 \%$ increase in economic growth and it is statistically significant.

Model II presents the results of exports of diamonds and economic growth. The results show that a reduction in exports of diamonds will have a coefficient of 0.064 , and an increase in exports of diamonds will have a coefficient of 0.134 . Therefore, in the long run a $1 \%$ increase in exports of diamonds will have a $0.098 \%$ increase in economic growth and is statistically significant at the $5 \%$ level. On other hand, a $1 \%$ decrease in exports of diamonds will have a $0.080 \%$ increase in economic growth, but this is not statistically significant. The results also show that a $1 \%$ decrease in imports of machinery will cause a $0.107 \%$ decrease in economic growth. A $1 \%$ increase in imports or machineries and appliances will cause economic growth to decrease by $0.069 \%$. In both cases only the parameter for import of machinery is statistically significant at 10\%. A $1 \%$ decrease in inflation rate will lead to a $0.005 \%$ decrease in economic growth. Alternatively, a 1\% increase in inflation will lead to a $0.006 \%$ increase in economic growth, but this coefficient is not statistically significant.

Model III presents the results for exports of food and live animals and economic growth. The result indicates that a decrease in exports of food and live animals has a coefficient of -0.138 , and it is not statistically significant. In addition, an increase in exports of food and other products has a coefficient of -0.318 and it is statistically significant. Therefore, in the long run a $1 \%$ increase in exports of food and live animals will lead to a $0.144 \%$ increase in economic growth. A $1 \%$ decrease in exports of food and live animals will lead to a $0.062 \%$ decrease in economic growth. A $1 \%$ decrease in imports of machinery, mechanical and electrical appliances will lead to a $0.019 \%$ decrease in economic growth. A $1 \%$ increase in imports of machinery, mechanical and electrical appliances will cause economic growth to increase by $0.147 \%$. If inflation rate decreases by $1 \%$, economic growth will decrease by $0.007 \%$. However, a $1 \%$ increase in inflation will lead to a $0.008 \%$ increase in economic growth. The coefficients of both increase and decrease in inflation rates are statistically significant at the $1 \%$ level. All the estimated models have an acceptable adjusted $R$-squared of more than $81 \%$.

It is important to test whether there exists asymmetry in the relationship between variables. The presence of asymmetry 
TABLE 6: Non-linear autoregressive distributive lag bound test cointegration results.

\begin{tabular}{|c|c|c|c|c|c|c|c|}
\hline \multirow[t]{2}{*}{ Models } & \multirow[t]{2}{*}{$F$-statistics } & \multicolumn{2}{|c|}{$10 \%$ critical value } & \multicolumn{2}{|c|}{$5 \%$ critical value } & \multicolumn{2}{|c|}{$1 \%$ critical value } \\
\hline & & $I(0)$ & I(1) & $I(0)$ & I(1) & $I(0)$ & I(1) \\
\hline Model I & $27.694 *$ & 2.592 & 3.454 & 3.100 & 4.088 & 4.310 & 5.544 \\
\hline Model II & $11.174 *$ & 2.592 & 3.454 & 3.100 & 4.088 & 4.310 & 5.544 \\
\hline Model III & $16.603^{*}$ & 2.592 & 3.454 & 3.100 & 4.088 & 4.310 & 5.544 \\
\hline
\end{tabular}

Note: Null hypothesis: no cointegration; Alternative hypothesis: cointegration; Rejection rule: reject null hypothesis if $F$-statistic is upper than the upper limit.

$*, 1 \%$ significance level.

TABLE 7: Non-linear autoregressive distributive lag long-run estimation results.

\begin{tabular}{|c|c|c|c|c|c|c|}
\hline \multirow[t]{2}{*}{ Variables } & \multicolumn{2}{|c|}{ Model I } & \multicolumn{2}{|c|}{ Model II } & \multicolumn{2}{|c|}{ Model III } \\
\hline & Coefficient & $t$-statistic & Coefficient & $t$-statistic & Coefficient & $t$-statistic \\
\hline INTERCEPT & 20.178 & $10.761 *$ & 13.605 & $7.726^{*}$ & 21.667 & 10.604 \\
\hline LGDP & -2.043 & -10.642 & -1.370 & $-7.625^{*}$ & -2.204 & -10.572 \\
\hline LIMP_N-1 & -0.464 & $-3.450 *$ & 0.147 & $1.782 * *$ & -0.043 & -0.438 \\
\hline LIMP_P-1 & 0.213 & $4.700 *$ & 0.094 & 1.562 & 0.324 & $5.971 *$ \\
\hline INF_N-1 & 0.001 & 0.147 & 0.008 & 0.885 & -0.015 & $-2.699 *$ \\
\hline INF_P-1 & 0.046 & $6.216^{*}$ & 0.008 & 1.038 & 0.017 & $2.491 *$ \\
\hline LMNEXT_P-1 & -0.703 & $-6.600 *$ & - & - & - & - \\
\hline LMNEXT_N-1 & -0.164 & -1.101 & - & - & - & - \\
\hline LDEXT_P-1 & - & - & 0.134 & $1.855^{* *}$ & - & - \\
\hline LDEXT_N-1 & - & - & 0.064 & 0.622 & - & - \\
\hline LFHEXT_P-1 & - & - & - & - & -0.318 & $-3.401 *$ \\
\hline LFHEXT_N-1 & - & - & - & - & -0.138 & -1.422 \\
\hline R-squared & 0.974 & - & 0.946 & - & 0.941 & - \\
\hline
\end{tabular}

Note: _N describes disaggregated decrease in exports and _ $\mathrm{P}$ is disaggregated increase in exports.

$*, 1 \%$ significance level; **, $5 \%$ significance level.

TABLE 8: Long-run asymmetric test.

\begin{tabular}{|c|c|c|c|c|c|c|}
\hline \multirow{2}{*}{$\begin{array}{l}\text { Asymmetric null } \\
\text { hypothesis }\end{array}$} & \multicolumn{2}{|c|}{ Model I } & \multicolumn{2}{|c|}{ Model II } & \multicolumn{2}{|c|}{ Model III } \\
\hline & Wald test & Probability & Wald test & Probability & Wald test & Probability \\
\hline$-\gamma_{1}^{-} / \beta_{1}=-\gamma_{2}^{+} / \beta_{1}$ & 32.401 & $(0.000)^{*}$ & 1.515 & $(0.241)$ & 14.553 & $(0.001)^{*}$ \\
\hline
\end{tabular}

Note: $F$-statistics ( $p$-value)

*, Indicates rejection of the null hypothesis of no asymmetry.

TABLE 9: Diagnostic test results.

\begin{tabular}{|c|c|c|c|c|c|c|}
\hline \multirow[t]{2}{*}{ Residual and stability tests } & \multicolumn{2}{|c|}{ Model I } & \multicolumn{2}{|c|}{ Model II } & \multicolumn{2}{|c|}{ Model III } \\
\hline & Test statistic & Probability & Test statistic & Probability & Test statistic & Probability \\
\hline Normality - Jarque-Bera & 1.615 & 0.445 & 1.597 & 0.449 & 2.456 & 0.292 \\
\hline Heteroskedasticity test & 21.751 & 0.594 & 30.449 & 0.170 & 28.081 & 0.173 \\
\hline Ramsey RESET test (stability) & 3.441 & 0.065 & 0.461 & 0.716 & 0.551 & 0.657 \\
\hline
\end{tabular}

RESET, regression specification error test.

will simply indicate that the computed 'positive' and 'negative' series have different effects on the dependent variable. The study makes use of the Wald test to determine the asymmetry. The results are presented in Table 8 . Table 8 demonstrates that the null hypothesis of 'no asymmetry' is rejected for Model I and Model III.

After estimating the NARDL model for Equation 5 with its disaggregated exports (Models I, II and II), diagnostic tests were carried out to assess the validity of the models. The results show that the null hypothesis of normality of residuals cannot be rejected. The model also passed the test for heteroskedasticity and stability (see Table 9).

\section{Conclusion}

This study investigates the asymmetric (non-linear) relationship between exports and economic growth in Namibia.
This study differs from previous studies in the sense that it does not just investigate the relationship between the two variables at an aggregate level, but for the main export sectors of the Namibian economy. The non-linear relationship between export and economic growth was investigated for exports of manufactured products, diamonds, and food and live animals. These are the main export sectors of the Namibian economy and were selected because of availability of consistent time series data. The study used quarterly data and covers the period 2009-2018. The study applied the NARDL model to capture the long-run asymmetric relations between disaggregated exports and economic growth. The results show that in the long run there is evidence of an asymmetric relationship between disaggregated exports and economic growth in Namibia. The results indicated that a decrease in exports of manufactured products, diamonds, and food and live animal products will significantly cause economic growth to deteriorate. An increase in exports of these products will 
cause economic growth to improve significantly. The results therefore indicate that increase and decrease in exports of these products will have different effects on economic growth. The main contribution of this study is that it did not just test the non-linear relationship between the two variables (export and economic growth); it investigated the relationship between the two variables for the main export sectors of the Namibian economy. This will mean that we do not develop only one economic policy for all sectors; it will ensure that economic policies are sector specific. For example, an economic policy that is good for the diamond sector may not be appropriate for the food and live animal sectors. The study further recommends that when there is a decrease in export, it will be appropriate to pursue expansionary policies in order to improve economic growth.

\section{Acknowledgements}

The author would like to thank the National Research Foundation (NRF) for funding that partially contributed to the finalisation of this research. The authors would also like to thank Hilda Ampweya (from Namibia Statistics Agency) for her assistance with the data.

\section{Competing interests}

The authors have declared that no competing interest exist.

\section{Authors' contributions}

All authors made equal contributions.

\section{Ethical consideration}

This article followed all ethical standards for carrying out research.

\section{Funding information}

The author would like to thank the National Research Foundation (NRF) for funding that partially contributed to the finalisation of this research.

\section{Data availability statement}

Data sharing is not applicable to this article.

\section{Disclaimer}

The views and opinions expressed in this article are those of the authors and do not necessarily reflect the official policy or position of any affiliated agency of the authors.

\section{References}

Aladejare, S.A. \& Saidi, A., 2014, 'Determinants of non-oil export and economic growth in Nigeria: An application of the bound test approach', Journal for the Advancement of Developing Economies 3, 68-81.
Amavilah, V.H., 2003, Exports and economic growth in Namibia, 1968-1992, University of Arizona Working Paper, Tucson, AZ.

Breitung, J., 2002, 'Nonparametric tests for unit roots and cointegration', Journal of Econometrics 108, 343-363. https://doi.org/10.1016/S0304-4076(01)00139-7

Brock, W., Dechert, D., Sheinkman, J. \& LeBaron, B., 1996, 'A test for independence based on the correlation dimension', Econometric Reviews 15(3), 197-235. https://doi.org/10.1080/07474939608800353

Busse, M. \& Königer, J., 2012, Trade and economic growth: A re-examination of the empirical evidence, HWWI Research Paper 123, Hamburg Institute of International empirical evidence, $\mathrm{HW}$
Economics, Hamburg.

Din, M., 2004, 'Exports, imports, and economic growth in South Asia: Evidence using a multivariate time-series framework', The Pakistan Development Review 43, 105-124. https://doi.org/10.30541/v43i2pp.105-124

Dollar, D. \& Kraay, A., 2005, 'Spreading the wealth', in P. King \& S. King (eds.), International economics and international economic policy, pp. 183-196, McGraw-Hill, Boston.

Dritsakis, N., 2006, 'Exports and economic growth: An empirical investigation of EU, USA and Japan using causality tests', International Review of Applied Economic Research 1, 79-92.

Gurgul, H. \& Lach, L., 2010, 'International trade and economic growth in the Polish economy', Operations Research and Decisions 3-4, 5-29.

Hatem, J.A. \& Uddin, G.S., 2012, 'Is the causal nexus of energy utilization and economic growth asymmetric in the US?', Economic System 36, 461-469. https://doi. org/10.1016/j.ecosys.2011.10.005

Helpman, E. \& Krugman, P., 1985, Market structure and foreign trade, MIT Press, Cambridge, MA.

Jordaan, A.C. \& Eita, J.H., 2007, 'Export and economic growth in Namibia: A Granger causality analysis', South African Journal of Economics 75, 540-547. https://doi. org/10.1111/j.1813-6982.2007.00132.x

Kapetanios, G., Shin, Y. \& Snell, A., 2003, 'Testing for cointegration in nonlinear smooth transition error correction models', Econometric Theory 22, 279-303. https://doi.org/10.2139/ssrn.428602

Mishra, P.K., 2011, 'The dynamics of relationship between exports and economic growth in India', International Journal of Economic Sciences and Applied Research 4, 53-70.

Molapo, S. \& Damane, M., 2016, 'The export-led growth hypothesis in Lesotho: A case of the mining industry', Paper presented at the TIPS forum 2016: On Industrialisation and the Mining Economy, Johannesburg, South Africa, June.

Mtaturu, J., 2016, 'The relationship between export and economic growth in Tanzania: Granger causality approach (1976-2013)', Business Education Journa (BEJ) I, 1-17.

Narayan, P.K., 2005, 'The saving and investment nexus for China: Evidence from cointegration tests', Applied Economics 37, 1979-1990. https://doi.org/10.1080/ 00036840500278103

Niishinda, E. \& Ogbokor, C.A., 2013, 'Testing the long-run relationship between export and economic growth: Evidence from Namibia', Journal of Emerging Issues in Economics, Finance and Banking (JEIEFB) 1, 244-261.

Ogbokor, C.A., 2015, 'Foreign trade and economic growth in Namibia: A time series analysis', PhD thesis, North-West University, Mmabatho-Mafikeng.

Ogbokor, C.A. \& Meyer, M.D., 2016, 'An econometric time-series analysis of the dynamic relationship between foreign trade and economic growth in a developing country: Evidence from Namibia', Acta Universitatis Danubius Oeconomica 12(4), 153-170.

Pesaran, M.H., Shin, Y. \& Smith, R.J., 2001, 'Bounds testing approaches to the analysis of level relationships', Journal of Applied Econometrics 16, 289-326. https://doi. org/10.1002/jae.616

Phiri, M. \& Bhatia, A., 2017, African economic outlook 2017, viewed 26 June 2018 from https://www.undp.org/content/dam/rba/docs/Reports/African_Economic Outlook_2017_EN.pdf.

Rangasamy, L., 2009, 'Exports and economic growth: The case of South Africa', Journal of International Development 21, 603-617. https://doi.org/10.1002/jid.1501

Salvatore, D., 2011, International economics, trade and finance, Wiley and Sons, Singapore.

Shihab, R.A. \& Abdul-Khaliq, T.S.S., 2014, 'The causal relationship between exports and economic growth in Jordan', International Journal of Business and Social Science 5, 302-308.

Simasiku, C. \& Sheefeni, J.P.S., 2014, 'Terms of trade and economic growth in Namibia', International Review of Research in Emerging Markets and the Global Economy (IRREM) 1, 90-101.

Simasiku, C. \& Sheefeni, J.P.S., 2017, 'Agricultural exports and economic growth in Namibia', European Journal of Basic and Applied Sciences 4, 41-50.

Shin, Y., Yu, B.C. \& Greenwood-Nimmo, M., 2014, 'Modelling asymmetric cointegration and dynamic multipliers in a nonlinear ARDL framework', in R. Sickels \& W. Horrace (eds.). Festschrift in honor of Peter Schmidt: Econometric methods and applications, pp. 281-314, Springer, New York.

United Nations Conference on Trade and Development (UNCTAD), 2016, Namibia trade policy framework, United Nations, New York.

World Bank, 1993, The East Asian miracle experience: Economic growth and public policy, Oxford University Press, Oxford. 